\title{
STUDI IMPLEMENTASI MBKM PADA MAHASISWA, DOSEN DAN MITRA DI TINGKAT PRODI MANAJEMEN, AKUNTANSI, DAN TEKNIK INFORMATIKA DI UNIVERSITAS MUHAMMADIYAH PURWOKERTO
}

\author{
Suryo Budi Santoso*, Herni Justiana Astuti, Hadi Pamono, Nur Isna Inayati, Muhammad Hamka
}

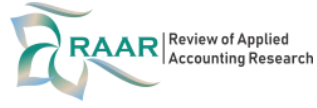

Affiliation:

Accounting Department, Universitas Muhammadiyah

Purwokerto, Indonesia

\section{*Correspondence:}

suryobs@gmail.com

Article Process:

Submitted:

January 31, 2022

Reviewed:

February 4, 2022

Revised:

February 10, 2022

Accepted:

February 12, 2022

Published:

February 15, 2022

\section{Citation:}

Santoso. S. B, H. J Astuti, H.

Pamono, N. I. Inayati, M. Hamka.

(2022). Studi Implementasi

MBKM Pada Mahasiswa, Dosen

Dan Mitra Di Tingkat Prodi

Manajemen, Akuntansi, Dan

Teknik Informatika Di Universitas Muhammadiyah Purwokrto.

RAAR: Review of Applied

Accounting Research, 2 (1), 279303.

\section{Office Address:}

Jl. K.H. Ahmad Dahlan,

Dukuhwaluh, Kec.

Kembaran, Kabupaten

\begin{abstract}
ABSTRAK
Tujuan dari penelitian ini adalah Untuk mengevaluasi Implementasi MBKM pada Mahasiswa, Dosen dan Mitra. Jenis penelitian ini adalah penelitian lapangan (field ressearch), Sumber data penelitian ini adalah data primer. Populasi dalam penelitian ini adalah Seluruh Mahasiswa Prodi: Akuntansi S1, Manajemen S1, dan Teknik Informatika S1 UMP; Seluruh Dosen Prodi Akuntansi S1, Manajemen S1, dan Teknik Informatika S1 UMP; Seluruh mitra yang bekerja sama dalam program MBKM. Sampel pada penelitian ini menggunakan purposive sampling. Analisis data yang digunakan dalam analisis kuantitatif yang digunakan dengan angka-angka. Analisis data yang digunakan dalam penelitian ini adalah analisis deskriptif dan intepretasi. Hasil penelitian ini adalah Program MBKM merupakan program baru, sehingga masih dalam tahap penyesuaian untuk mencapai optimalisasi program. Namun demikian dampak pelaksanaan program MBKM sudah dirasakan mahasiswa dan dosen. Mahasiswa dapat belajar aplikasi keilmuan dan softskill dari program magang. Dosen pendamping juga dapat menerima masukan yang aplikatif dari dari mitra, untuk dapat diterapkan pada proses pembelajaran
\end{abstract}

Kata kunci: Implementasi MBKM pada Mahasiswa, Dosen dan Mitra

\section{ABSTRACT}

The purpose of this research is to develop the implementation of MBKM on students, lecturers and partners. This type of research is field research. The source of this research data is primary data. The population in this study were all students of the S1 Accounting Study Program, S1 Management, and Informatics Engineering S1 UMP; All Lecturers of S1 Accounting Study Program, S1 Management, and Informatics Engineering S1 UMP; All partners who work together in the MBKM program. The sample in this study used purposive sampling. Analysis of the data used in the quantitative analysis used with numbers. The data analysis used in this research is descriptive analysis and interpretation. The result of this research is that the MBKM program is a new program, so it is still in the adjustment stage to achieve program optimization. However, the impact of the implementation of the MBKM program has been felt by students and lecturers. Students can learn scientific applications and soft skills from the internship program. Companion lecturers can also receive applicable input from partners, to be applied to the learning process. 
Kampus Merdeka merupakan wujud pembelajaran di perguruan tinggi yang otonom dan fleksibel sehingga tercipta kultur belajar yang inovatif, tidak mengekang, dan sesuai dengan kebutuhan mahasiswa (RI, 2020).

Proses belajar Kampus Merdeka di Program Studi Manajemen dan Akuntansi S1 Fakultas Ekonomi dan Bisnis dan Teknik Informatika Fakultas Teknik dan Sains Universitas Muhammadiyah Purwokerto sebagai berikut:

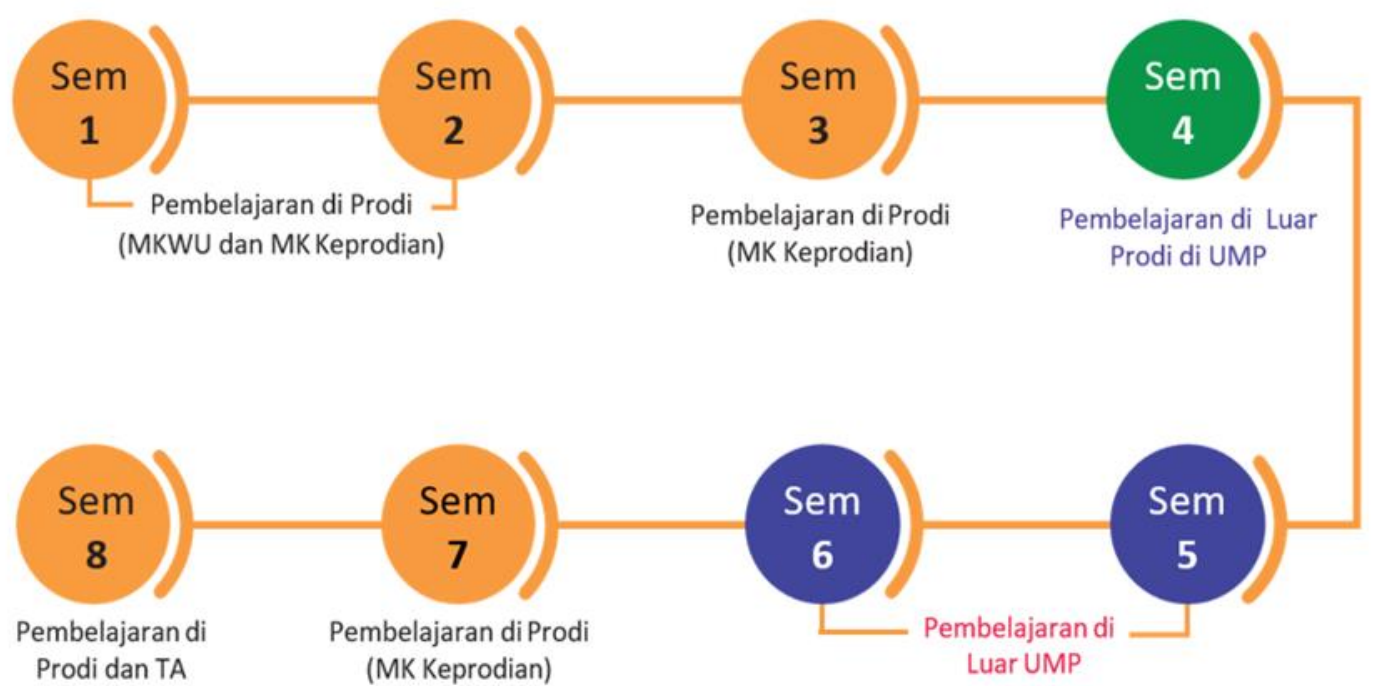

Gambar 1.1. Proses belajar Kampus Merdeka UMP

Pola Kurikulum MBKM yang ditetapkan adalah mengikuti pola 5-1-2 yaitu 5 semester pembelajaran di dalam prodi, 1 semester di luar prodi dalam perguruan tinggi yang sama, dan 2 semester pembelajaran di luar universitas. Implementasi MBKM ini dilaksanakan pada semester 4, 5 dan 6. Semester 4 (empat) merupakan pembelajaran di luar prodi pada prodi di UMP sebanyak maksimal 20 SKS. Semester 5 dan 6 merupakan pembelajaran di luar universitas yang terdiri dari Pertukaran Mahasiswa, Magang, Asisten Mengajar di satuan pendidikan, Penilitian/Riset; Proyek Kemanusian, Kegiatan Wirausaha, Studi/Proyek Independen, dan proyek di desa/KKNT. Pembelajaran di luar universitas distrukturkan sesuai dengan kurikulum yang ditempuh oleh mahasiswa. Jumlah SKS pembelajaran di luar universitas sebanyak 20-40 SKS dinyatakan dalam bentuk kesetaraan dengan mata kuliah yang ditawarkan prodi. Pelaksanaan pembelajaran di luar universitas diatur dengan perjanjian kerjasama.

Pelaksanaan MBKM di Prodi Manajemen S1 terdiri dari 16 mahasiswa magang di Perbankan, 20 Program Kewirausahaan dan 8 mahasiswa mendampingi UMKM, 34 mengikuti program Kampus Mengajar, 1 orang mengikuti Program KKMI, 5 mahasiswa mengikuti studi Independen dan 5 mengikuti Program Pertukaran Mahasiswa di Universitas Ahmad Dahlan. Sedangkan Program studi Akuntansi S1, 8 mahasiswa mengikuti kampus mengajar, 6 mahasiswa mengikuti KKMI, 2 mahasiswa mengikuti Studi Independen.

Program MBKM ini adalah program baru yang masih menimbulkan banyak tanda tanya bagi mahasiswa, dosen dam mitra. Khususnya implementasi di lapangan. Diperlukan kajian mendalam agar link and match dengan industri dapat dilaksanakan dengan maksimal. Pelaksanaan MBKM di Fakultas Ekonomi dan Bisnis dan Fakultas Teknik dan Sains sudah berlangsung di Semester Gasal Tahun Akademik 2021/2022. Mitra tempat magang menyampaikan jika mahasiswa masih menunggu diberi pekerjaan dan kurang adanya inisiatif khususnya yang magang di UMKM. Oleh Vol.2 No.1 karena itu masih perlu dilakukan kajian evaluasi implementasi MBKM bagi mahasiswa, dosen dan mitra sehingga kedepannya pelaksanaan MBKM bisa memberikan dampak yang maksimal bagi semuanya. 
Tujuan dari penelitian ini adalah

1. Untuk mengevaluasi Implementasi MBKM pada Mahasiswa

2. Untuk mengevaluasi Implementasi MBKM pada Dosen

3. Untuk mengevaluasi Implementasi MBKM pada Mitra

\section{METODE PELAKSANAAN}

\section{Jenis Penelitian}

Jenis penelitian ini adalah penelitian lapangan (field ressearch) yakni pengamatan langsung terhadap obyek yang diteliti guna mendapatkan data yang relevan. Metode yang akan digunakan dalam penelitian ini adalah dengan menggunakan metode penelitian analisis kuantitatif, yaitu menggunakan analisis data secara mendalam dalam bentuk angka (Sugiyono, 2017)

Sumber data penelitian ini adalah data primer. Data primer adalah data yang didapat peneliti dari sumber pertama baik individu atau perseorangan seperti hasil wawancara atau pengisian kuesioner yang biasa dilakukan oleh peneliti (Sugiyono, 2017).

\section{Populasi dan Sampel}

Populasi dalam penelitian ini adalah:

1. Seluruh Mahasiswa Prodi: Akuntansi S1, Manajemen S1, dan Teknik Informatika S1 UMP

2. Seluruh Dosen Prodi Akuntansi S1, Manajemen S1, dan Teknik Informatika S1 UMP

3. Seluruh mitra yang bekerja sama dalam program MBKM

Sampel pada penelitian ini menggunakan purposive sampling dengan kriteria:

1. Sampel mahasiswa:

a. Minimal mahasiswa aktif semester IV,

b) Pernah mengambil MBKM.

2. Sampel dosen:

Seluruh dosen prodi Akuntansi S1, Manajemen S1, dan Teknik Informatika S1 UMP

3. Sampel mitra:

Seluruh mitra yang pernah melaksanakan program MBKM

\section{Metode Penelitian}

Pengumpulan data dalam penelitian ini menggunakan sumber primer. Sumber primer adalah sumber data yang langsung memberikan data kepada pengumpul data (Sugiyono : 137). Teknik pengambilan data dalam penelitian ini menggunakan kuesioner dan wawancara. Kuesioner diberikan secara langsung kepada responden dosen dan mahasiswa. Waktu yang ditentukan dalam pengumpulan data adalah maksimal 1 minggu.

Penyusunan kuisioner dengan cara:

a. Studi literatur

b. Mendapat masukan dari FGD dengan stakeholder

c. Indikator-indikator dan dimensi pertanyaan ditentukan

d. Tim peneliti melanjutkan menyelesaikan indikator dan dimensi tersebut ke dalam pertanyaan kuisioner (baik tertutup dan terbuka).

\section{Metode Analisis Data}

Analisis data yang digunakan dalam analisis kuantitatif yang digunakan dengan angka-angka. Analisis data yang digunakan dalam penelitian ini adalah analisis deskriptif dan intepretasi.

\section{Hasil Analisis Data Dosen}

\section{Statistik Deskriptif}

Dosen sebagai responden sebanyak 32 dosen dan memberikan jawaban dengan pertanyaan tertutp dan terbuka. Pertanyaan tertutup dengan memberikan jawaban dengan 5 pilihan skala sikap. Berdasarkan jawaban kuesioner dosen diperoleh hasil uji statistic deskriptif seperti yang disajika dalam tabel 2.1

Tabel 2.1 Tabel uji statistic deskriptif jawaban kuesioner dengan responden dosen 
Descriptive Statistics

\begin{tabular}{|l|r|r|r|r|r|}
\hline & $\mathrm{N}$ & Minimum & Maximum & Mean & Std. Deviation \\
\hline $\mathrm{X} 1$ & 32 & 2.00 & 5.00 & 3.9688 & .82244 \\
$\mathrm{X} 2$ & 32 & 1.00 & 5.00 & 3.5313 & 1.04679 \\
$\mathrm{X} 3$ & 32 & 2.00 & 5.00 & 4.0938 & .68906 \\
$\mathrm{X} 4$ & 32 & 1.00 & 5.00 & 3.7812 & .90641 \\
$\mathrm{X} 5$ & 32 & 2.00 & 5.00 & 3.6875 & .85901 \\
$\mathrm{X} 6$ & 32 & 2.00 & 5.00 & 4.0625 & .71561 \\
X7 & 32 & 1.00 & 5.00 & 3.8750 & .75134 \\
$\mathrm{X} 8$ & 32 & 3.00 & 5.00 & 4.1562 & .62782 \\
$\mathrm{X} 9$ & 32 & 2.00 & 5.00 & 4.0313 & .69488 \\
X10 & 32 & 2.00 & 5.00 & 4.0938 & .68906 \\
$\mathrm{X} 11$ & 32 & 1.00 & 5.00 & 3.7188 & .95830 \\
X12 & 32 & 2.00 & 5.00 & 4.1250 & .70711 \\
$\mathrm{X} 13$ & 32 & 2.00 & 5.00 & 3.8438 & .88388 \\
$\mathrm{X} 14$ & 32 & 3.00 & 5.00 & 4.2500 & .50800 \\
X15 & 32 & 1.00 & 5.00 & 2.6875 & 1.11984 \\
Rata2 & 32 & 2.33 & 4.67 & 3.8603 & .51327 \\
Valid N & 32 & & & & \\
(listwise) & & & & & \\
\hline
\end{tabular}

Berdasarkan tabel 2.1 bahwa nilai rata-rata pernyataan tertinggi pada kuesioner nomor X14 sebesar 4,25 dapat diartikan bahwa Implementasi program magang/MBKM perlu ada perbaikan. Hal ini mengindikasikan bahwa semua dosen setuju jika diperlukan adanya perbaikan dari magang. Pihak pengelola harus mencari masukan dari mitra dan mahasiswa serta dosen pembimbing lapangan untuk perbaikan impelentasi MBKM untuk magang. Sedangkan nilai rata-rata terendah pada pernyataan nomor X15 sebesar 2,69 dapat diartikan bahwa pelaksanaan program magang/MBKM tidak memiliki hambatan. Hal ini mengindikasikan bahwa program MBKM masih memiliki hambatan dalam pelaksanaannya. Secara keseluruhan pelaksaan MBKM dari tinjauan dosen menyatakan bahwa rata-rata sebesar 3,86 atau mendekata setuju, meskipun harus ada pembenahan dalam pelaksanaannya.

2. Jawaban kuesioner dengan responden dosen per - item pernyataan

a. Informasi kebijakan MBKM mudah diakses

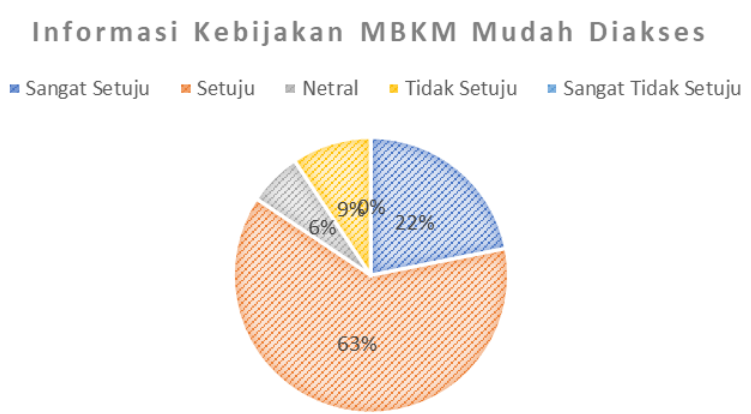

Gambar 2.1. Pie Cart Informasi kebijakan MBKM mudah diakses

Informasi kebijakan MBKM mudah diakses dikalangan dosen menyatakan dominan setuju sebesar 63 persen, dan selanjutnya menyatakan sangat setuju sebesar 22 persen. Artinya secara umum dan dominan, informasi kebijakan tentang MBKM mudah untuk di akses.

b. Saya terlibat aktif dalam implementasi program magang/MBKM 


\section{Saya terlibat aktif dalam implementasi}

program magang/MBKM
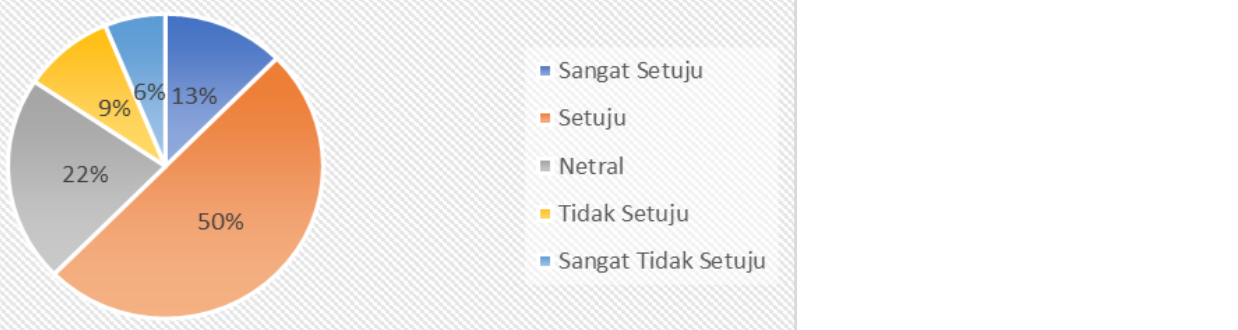

Gambar 2.2. Pie Chart Saya terlibat aktif dalam implementasi program magang /MBKM

Berdasarkan gambar 2.2 bahwa dosen setuju terlibat aktif dalam implementasi program magang/MBKM sebesar 50\%, bahkan 13\% sangat setuju. Artinya lebih dari sebagian dosen sudah terlibat aktif dalam implementasi MBKM, sedangkan 22 persen selanjutnya menyatakan netral. sementara tidak setujju dan sangat tidak setuju sebesar 9 dan 6 persen.

c. Saya mengarahkan mahasiswa mengikuti program magang/MBKM

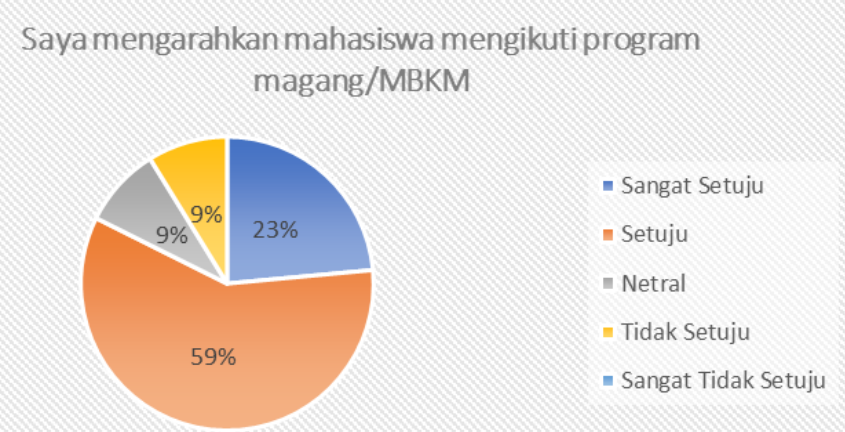

Gambar 2.3. Saya mengarahkan mahasiswa mengikuti program magang/MBKM

Keterlibatan dosen dalam mengarahkan mahasiswa dalam mengikuti program magang MBKM sebesar 59 persen setuju dan sangat setuju sebesar 23 persen. Artinya Bapak/ ibu dosen memberikan arahan pada mahasiswanya untuk mengikuti kegiatan MBKM.

d. Capaian Pembelajaran Lulusan (CPL) sejalan dengan implementasi MBKM

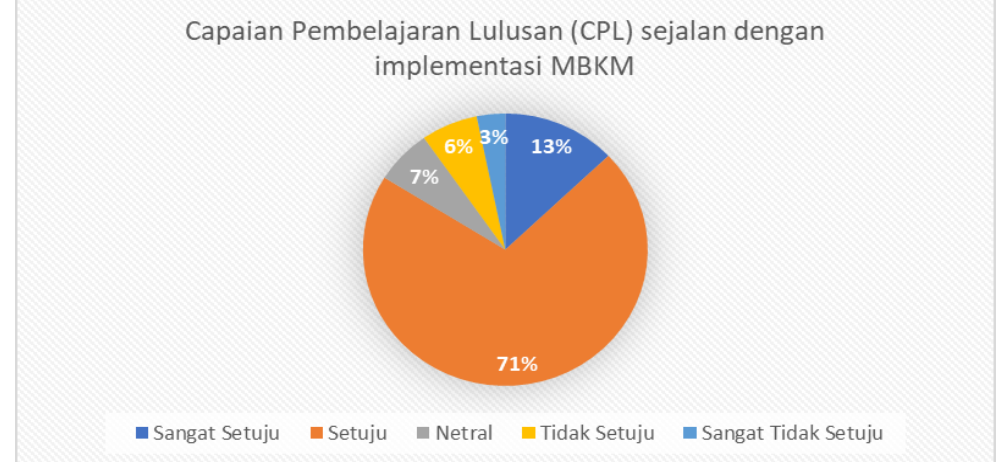

Gambar 2.4. Pie Chart Capaian Pembelajaran Lulusan (CPL) sejalan dengan implementasi MBKM

Berdasarkan gambar 2.4 bahwa menurut dosen bahwa pelaksanaan MBKM sudah sesuai dengan Capaian Pembelajaran Lulusan (CPL) program studi karena yang 
menyatakan setuju sebesar $71 \%$ dan $13 \%$ sangat setuju. Hanya $3 \%$ yang sangat tidak setuju.

e. Panduan MBKM mudah dipahami

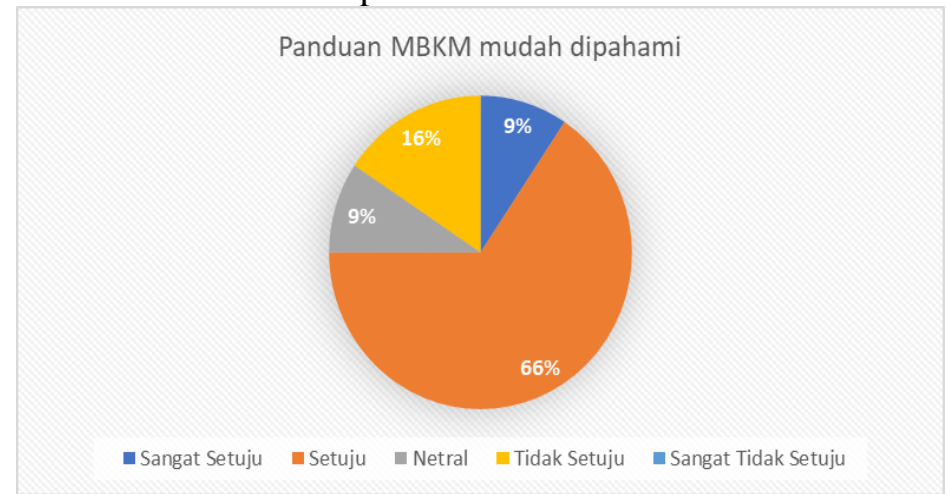

Gambar 2.5 Panduan MBKM mudah dipahami

Beradasarkan gambar 2.5 terdapat $66 \%$ dosen setuju bahwa panduan MBKM mudah dipahami bahkan $9 \%$ sangat setuju. Artinya lebih dari sebagian dosen sudah memahami panduan MBKM, hanya 16\% yang belum mudah memahami. Pihak pengelola harus mensosialisasikan lagi panduan tersebut ke semua dosen.

f. Mahasiswa diarahkan untuk mengikuti MBKM

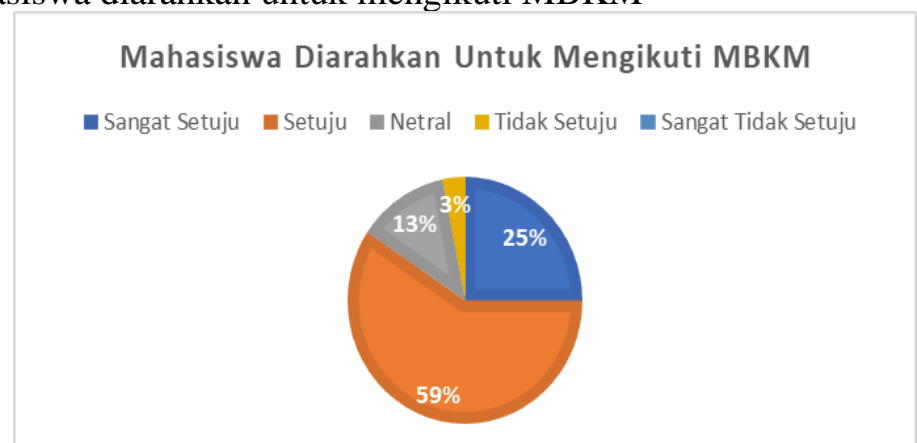

Gambar 2.6 Pie Chart Mahasiswa diarahkan untuk mengikuti MBKM

Berdasarkan gambar 2.6 menyatakan bahwa 58\% dosen telah mengarahkan mahasiswa untuk mengikuti MBKM bahkan 25\% sangat setuju, hanya 3\% dosen tidak setuju. Hal ini mengidikasikan bahwa dosen khususnya pembimbing akademik mengarahkan mahasiswanya untuk mengikuti MBKM

g. Fakultas memiliki program terdahulu yang serupa MBKM

Fakultas Memiliki Program Terdahulu Yang Serupa MBKM

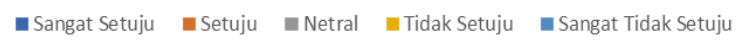

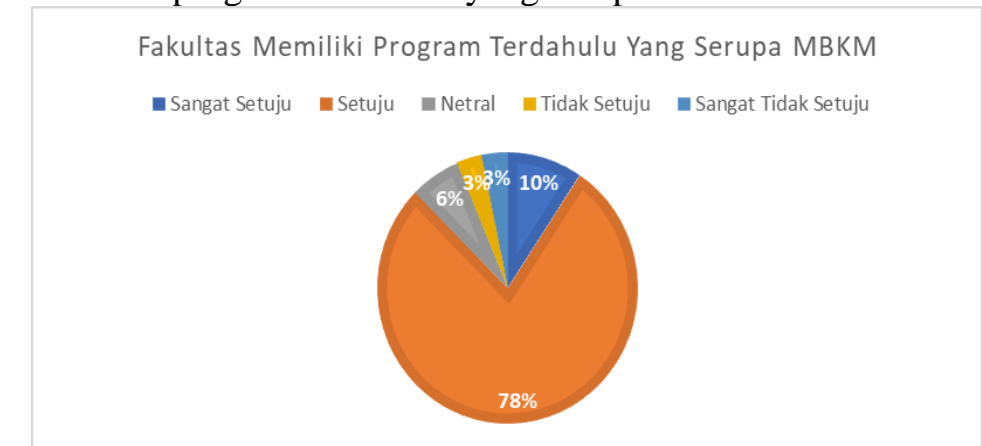

Gambar 2.7 Pie Chart Fakultas memiliki program terdahulu yang serupa MBKM
Vol.2 No.1 Berdasarkan gambar 2.7 bahwa 78\% dan 10\% dosen memahami bahwa Fakultas memiliki program terdahulu yang serupa MBKM, seperti magang di dalam negeri dan di luar negeri, mahasiswa 
bersama dosen melakukan penelitian bersama, Fakultas melakukan pembimbingan mahasiswa dalam kewirausahaan. Hanya 3\% dosen menganggap bahwa kegiatan serupa MBKM berbeda.

h. Pengalaman menjadi dosen pembimbing di program lain (misal: KWU, DPL KKN atau pertukaran mahasiswa) berguna dalam pendampingan mahasiswa magang/MBKM

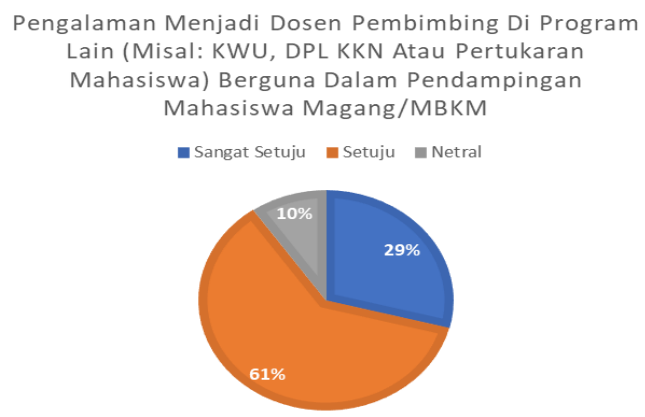

Gambar 2.8 Pie Chart Pengalaman menjadi dosen pembimbing di program lain (misal: KWU, DPL KKN atau pertukaran mahasiswa) berguna dalam pendampingan mahasiswa magang/MBKM Berdasarkan gambar 2.8 terlihat bahwa dosen menganggap bahwa mereka memiliki pengalaman menjadi Dosen Pembimbing Lapangan (DPL) dalam kebiatan Kuliah Kerja Nyata, menjadi mentor bagi mahasiswa dalam kewirausahaan berguna dalam pendampingan mahasiswa magang/MBKM sebanyak 90\%, sedangkan $10 \%$ masih menganggap bahwa pengalaman mereka hanya membantu sedikit.

i. Jumlah konversi SKS program magang/MBKM maksimal 20 SKS per semester

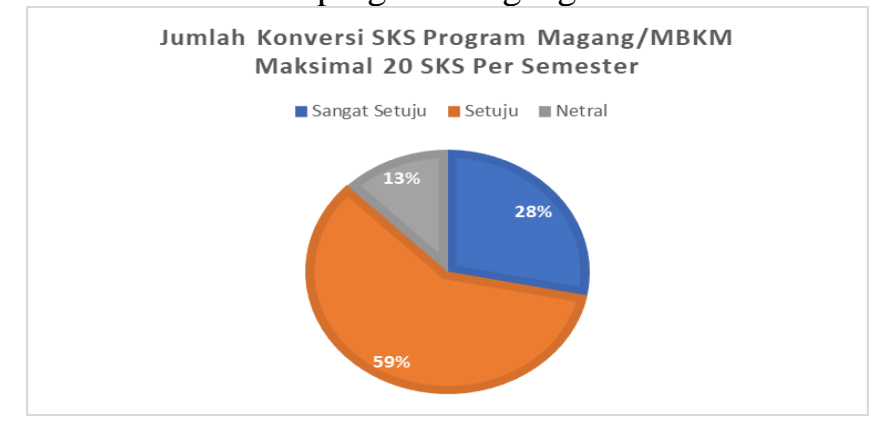

Gambar 2.9 Pie Chart Jumlah konversi SKS program magang/MBKM maksimal 20 SKS per semester

Berdasarkan gambar 2.9 bahwa dosen menganggap bahwa dalam program MBKM dapat dikonsversi dengan mata kuliah yang diambil pada program studi dengan maksimal 20 SKS sebanyak $87 \%$ (setuju dan sangat setuju) karena mereka sudah memahami panduan MBKM. Sedangkan $13 \%$ masih ragu-ragu.

j. Program magang/MBKM berdampak positif bagi proses pembelajaran mahasiswa

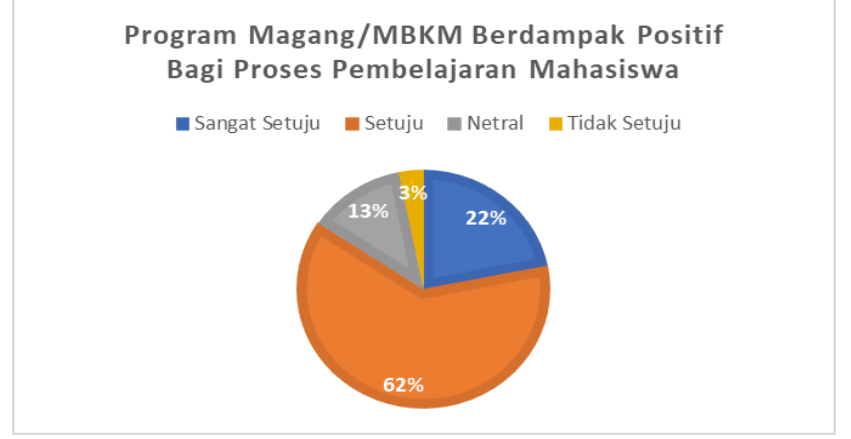


Gambar 2.10 Pie Chart Program magang/MBKM berdampak positif bagi proses pembelajaran mahasiswa

Berdasarkan gambar 2.10 dapat dijelaskan bahwa dosen menganggap program magang/MBKM berdampak positif bagi proses pembelajaran mahasiswa sebanyak $84 \%$ (setuju dan sangat setuju). Sedangkan 3\% dosen menganggap program magang kurang berdampak. Hal ini mengindikasikan bahwa program magang berdampak positif bagi mahasiswa.

k. Setelah melakukan pendampingan magang/MBKM, saya merasakan peningkatan kapasistas dosen

Setelah Melakukan Pendampingan Magang/MBKM,

Saya Merasakan Peningkatan Kapasistas Dosen

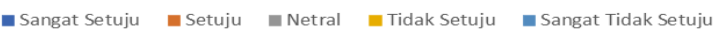

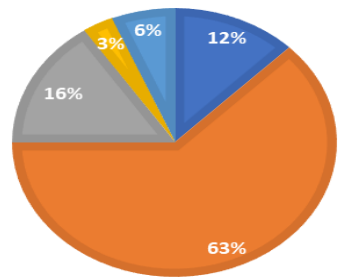

Gambar 2.11 Setelah melakukan pendampingan magang/MBKM, saya merasakan peningkatan kapasistas dosen

Berdasarkan gambar 2.11 terlihat bahwa dosen menganggap bahwa dengan adanya pengalaman sebagai DPL dalam Program MBKM, melakukan pembimbingan dan sebagainya, dosen merasa terdapat peningkatan kapasitas dosen sebanyak $75 \%$ (setuju dan sangat setuju), hanya $6 \%$ yang merasa belum bisa meningkatkan kapasitas dosen.

1. Saya merekomendasikan program magang/MBKM untuk mahasiwa angkatan berikutnya

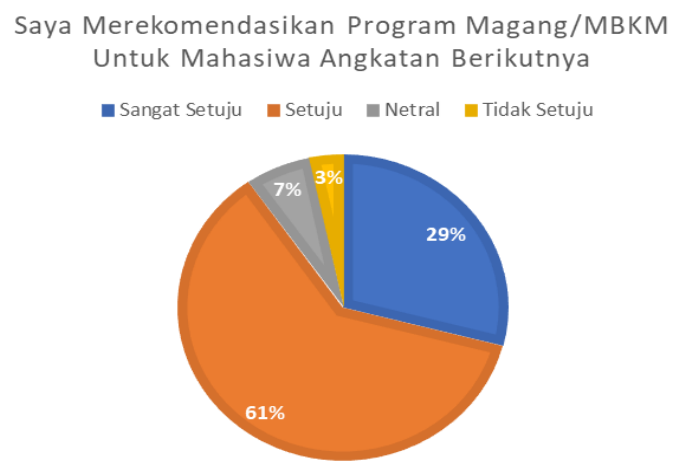

Gambar 2.12 Saya merekomendasikan program magang/MBKM untuk mahasiwa angkatan berikutnya

Berdasarkan gambar 2.12 dapat dijelaskan bahwa dosen akan merekomendasikan program magang/MBKM kepada mahasiswa angkatan berikutnya sebesar 90\% (setuju dan sangat setuju). Sedangkan $7 \%$ dosen masih ragu-ragu keberlanjutan program MBKM bahkan 3\% tidak merekomendasikan.

m. Tata cara penyetaraan program magang/MBKM ke dalam kurikulum prodi dilakukan terstruktur 


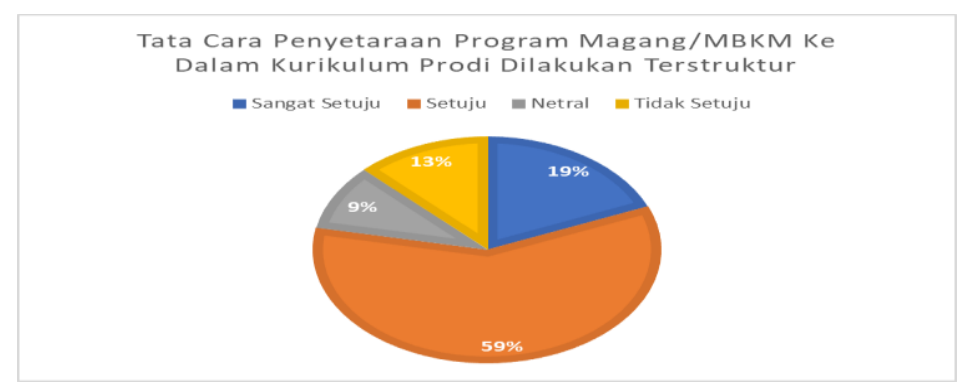

Gambar 2.13 Tata cara penyetaraan program magang/MBKM ke dalam kurikulum prodi dilakukan terstruktur.

Berdasarkan gambar 2.13 terlihat bahwa dosen menganggap bahwa tata cara penyetaraan program magang/MBKM ke dalam kurikulum prodi dilakukan terstruktur sebesar $78 \%$ (setuju dan sangat setuju), sedangkan $13 \%$ menganggap sebaliknya.

n. Implementasi program magang/MBKM perlu ada perbaikan

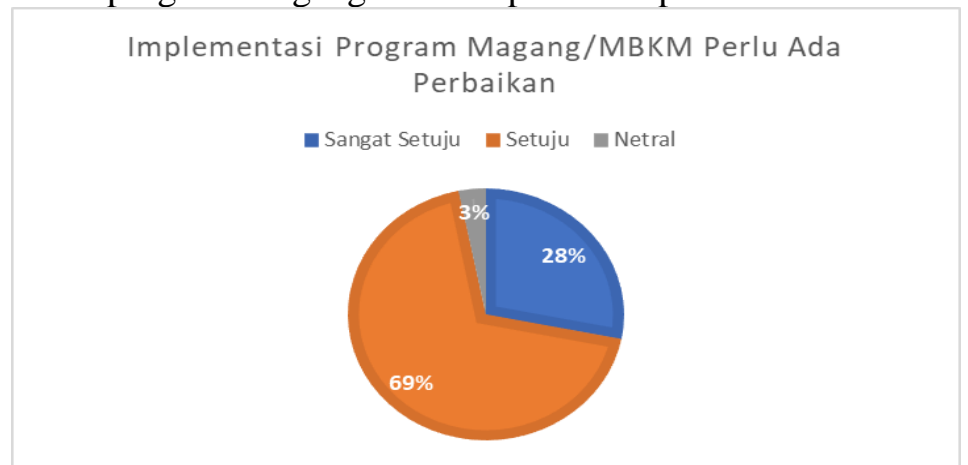

Gambar 2.14 Pie Chart Implementasi program magang/MBKM perlu ada perbaikan

Berdasarkan gambar 2.14 dijelaska bahwa meskipun dosen menganggap program MBKM bermanfaat namun implementasi program magang/MBKM perlu ada perbaikan sebanyak $97 \%$, sedangkan 3\% dosen sudah baik. Hal ini mengindikasikan bahwa pengelola program perlu melakukan perbaikan baik proses sebelum, saat dan sesudah magang.

o. Pelaksanaan program magang/MBKM tidak memiliki hambatan

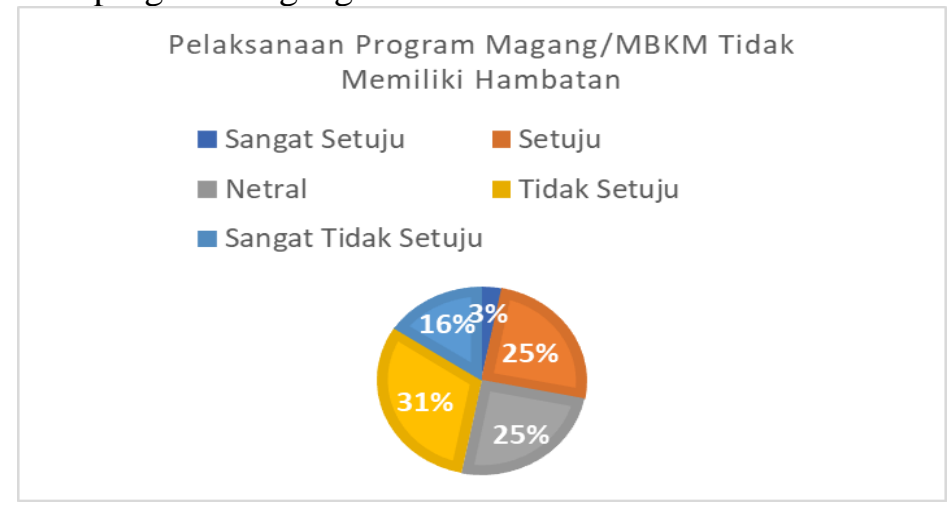

Gambar 2.15 Pelaksanaan program magang/MBKM tidak memiliki hambatan

Berdasarkan gambar 2.15 dosen menganggap bahwa program MBKM masih ada hambatan sebesar $28 \%$, sedangkan $47 \%$ sebaliknya, dan $25 \%$ masih ragu-ragu. Hal ini mengidikasikan bahwa program MBKM masih ada hambatan dan pengelola harus mengevaluasi setiap kegiatan MBKM.

Jawaban terbuka responden dosen 
Dosen sebagai responden juga memberikan jawaban dalam pertanyaan terbuka, seperti yang dijelaskan pada tabel berikut:

Tabel 2.2 Jawaban dosen atas pertanyaan Jelaskan Hambatan tersebut

\begin{tabular}{|c|l|r|}
\hline No & \multicolumn{1}{|c|}{ Jawaban } & \multicolumn{1}{|c|}{$\%$} \\
\hline 1 & $\begin{array}{l}\text { Mitra/instansi kurang mendapatkan informasi program MBKM sehingga } \\
\text { pemahaman yang berbeda antar mitra }\end{array}$ & $9 \%$ \\
\hline 2 & Koordinasi dengan DPL (pihak institusi/perusahaan) & $6 \%$ \\
\hline 3 & Sosialisasi program MBKM belum optimal & $9 \%$ \\
\hline 4 & Belum adanya kesepakatan terkait konversi MBKM & $9 \%$ \\
\hline 5 & Sistem dan Prosedur belum terbangun secara optimal & $6 \%$ \\
\hline 6 & Ada kendala pada kurang pahamnya mahasiswa pada tupoksi di tempat magang & $6 \%$ \\
\hline 7 & RPS untuk kegiatan MBKM perlu di perjelas & $3 \%$ \\
\hline 8 & $\begin{array}{l}\text { Belum jelasnya indikator penilaian dari dosen yang mahasiswanya tidak } \\
\text { mengikuti mata kuliah karena melakukan MBKM }\end{array}$ & $38 \%$ \\
\hline 9 & Tidak ada kendala & $100 \%$ \\
\hline \multicolumn{2}{|l|}{} \\
\hline
\end{tabular}

Berdasarkan tabel 2.2 bahwa 38\% dosen menganggap bahwa tidak ada hambatan untuk implementasi MBKM, 13\% dosen menganggap adanya hambatan pada konversi nilai dari aktivitas MBKM dengan mata kuliah yang diambil di semester yang berjalan. Pengelola MBKM perlu melakukan sosialisasi terkait kegiatan MBKM kepada mitra, dosen dan mahasiswa khususnya tupoksi ditempat magang.

Tabel 2.3 Jawaban atas pertanyaan usulan solusi atas hambatan

\begin{tabular}{|c|l|r|}
\hline No & \multicolumn{1}{|c|}{ Jawaban } & \multicolumn{1}{|c|}{$\%$} \\
\hline 1 & Sosialisasi teknis pelaksanaan MBKM & $16 \%$ \\
\hline 2 & $\begin{array}{l}\text { Prodi perlu mengkaji detail dalam bentuk panduan konversi/penilaian mata } \\
\text { kuliah apa saja dan indikator penilaian mahasiswa MBKM }\end{array}$ & $9 \%$ \\
\hline 3 & Perlu dibuatkan jadwal dan informasi yg terstruktur mengenai kegiatan MBKM & $13 \%$ \\
\hline 4 & $\begin{array}{l}\text { SOP dam indikatot MBKM untuk dosen, mahasiswa maupun tendik dan mitra } \\
\text { pendamping diperjelas }\end{array}$ & $6 \%$ \\
\hline 5 & Ada pembekalan sebelum magang & $19 \%$ \\
\hline 6 & $\begin{array}{l}\text { Komitmen seluruh komponen MBKM harus diseragamkan bahwa kegiatan } \\
\text { MBKM penting dilakukan }\end{array}$ & $\begin{array}{l}\text { Program lanjutan untuk pendampingan mahasiswa termasuk klasterisasi } \\
\text { kompetensi mahasiswa serta program ujikom untuk menambah portofolio }\end{array}$ \\
\hline 8 & $\begin{array}{l}\text { FGD secara rutin dan melibatkan semua dosen dan mitra, sehingga akan ada } \\
\text { kesamaan persepsi tentang MBKM }\end{array}$ & $6 \%$ \\
\hline & \multicolumn{1}{|c}{ Total } \\
\hline
\end{tabular}

Berdasarkan tabel 2.3 dapat dijelaskan bahwa saran perbaikan dari dosen adalah perlu adanya komitmen seluruh komponen MBKM harus diseragamkan bahwa kegiatan MBKM penting dilakukan sebesar $22 \%$, kemudian perlu adanya pembekalan sebelum magang sebesar 19\%, serta $16 \%$ responden menyarankan perlu adanya sosialisasi teknis pelaksanaan MBKM.

\section{RAAR Hasil Analisis Data Mahasiswa}

\section{Vol.2 No.1 1. Statistik Deskriptif}

mahasiswa sebagai responden sebanyak 33 mahasiswa dan memberikan jawaban dengan pertanyaan tertutup dan terbuka. Pertanyaan tertutup dengan memberikan jawaban dengan 5 
pilihan skala sikap. Berdasarkan jawaban kuesioner mahasiswa diperoleh hasil uji statistic deskriptif seperti yang disajika dalam tabel 1.1

Tabel 1.1 Tabel uji statistic deskriptif jawaban kuesioner dengan responden mahasiswa

\begin{tabular}{|c|c|c|c|c|c|}
\hline & $\mathrm{N}$ & Minimum & Maximum & Mean & Std. Deviation \\
\hline $\mathrm{X} 1$ & 33 & 3.00 & 5.00 & 4.4545 & 61699 \\
\hline $\mathrm{X} 2$ & 33 & 3.00 & 5.00 & 4.4545 & .56408 \\
\hline X3 & 33 & 2.00 & 5.00 & 4.1515 & .97215 \\
\hline $\mathrm{X} 4$ & 33 & 3.00 & 5.00 & 4.4848 & .56575 \\
\hline X5 & 33 & 3.00 & 5.00 & 4.5758 & .56071 \\
\hline X6 & 33 & 3.00 & 5.00 & 4.5455 & 61699 \\
\hline X7 & 33 & 3.00 & 5.00 & 4.4848 & 61853 \\
\hline X8 & 33 & 3.00 & 5.00 & 4.3333 & .59512 \\
\hline X9 & 33 & 3.00 & 5.00 & 4.3333 & .59512 \\
\hline X10 & 33 & 3.00 & 5.00 & 4.5152 & 61853 \\
\hline RATA2 & 33 & 3.40 & 5.00 & 4.4333 & .50662 \\
\hline $\begin{array}{ll}\text { Valid } & \mathrm{N} \\
\text { (listwise) } & \end{array}$ & 33 & & & & \\
\hline
\end{tabular}

Berdasarkan tabel 1.1 bahwa nilai rata-rata pernyataan tertinggi pada kuesioner nomor X5 sebesar 4,58 dapat diartikan bahwa mahasiswa merasakan program magang MBKM mampu meningkatkan kepercayaan diri. Hal ini mengindikasikan bahwa semua mahasiswa setuju bahwa dengan adanya magang percaya diri mereka tumbuh sehingga mereka merasa mampu menyelesaikan pekerjaan yang diberikan. Sedangkan nilai rata-rata terendah pada pernyataan nomor X3 sebesar 4,15. Meskipun rendah namun rata-rata mahasiswa setuju dengan pernyataan tersebut, dapat diartikan bahwa mahasiswa merasa program magang MBKM yang di konversi dengan mata kuliah sudah sesuai. Secara keseluruhan pelaksanaan MBKM dari tinjauan mahasiswa menyatakan bahwa rata-rata sebesar 4,43 atau rata-rata setuju atas pelaksanaan implementasi program MBKM melalui magang.

2. Jawaban kuesioner dengan responden dosen per - item pernyataan

a. Saya merasa program magang memberikan manfaat terhadap proses pembelajaran
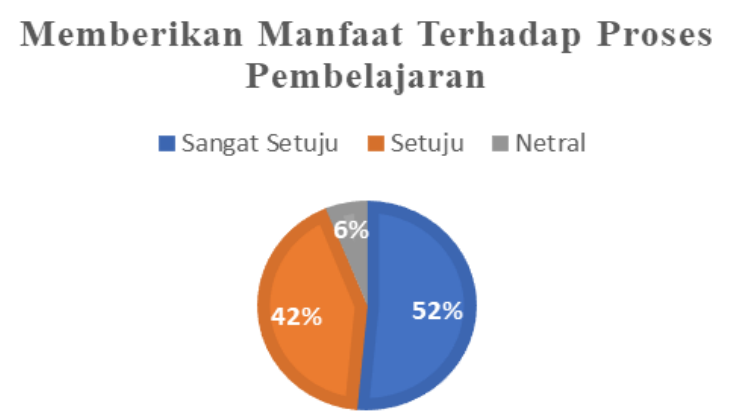

Gambar 1.1 Pie Chart memberikan manfaat terhadap proses pembelajaran

Berdasarkan gambar 1.1 dapat dijelaskan bahwa mahasiswa peserta magang merasa program magang memberikan manfaat terhadap proses pembelajaran sebesar $94 \%$ (setuju dan sangat setuju), sedangkan $6 \%$ merasa masih ragu akan manfaatnya.

b. Saya dapat mengimplementasikan ilmu yang diperoleh dari program studi di program Vol.2 No.1 magang MBKM 
Dapat Mengimplementasikan Ilmu Yang Diperoleh

- Sangat Setuju $\square$ Setuju $\square$ Netral

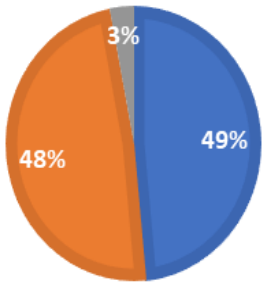

Gambar 1.2 Pie Chart dapat mengimplementasikan ilmu yang diperoleh

Berdasarkan gambar 1.2 dapat dijelaskan bahwa mahasiswa dapat mengimplementasikan ilmu yang diperoleh selama di program studi ke program magang MBKM sebesar 97\%, sedangkan yang masih ragu-ragu hanya $3 \%$.

c. Saya merasa Program magang MBKM yang di konversi dengan mata kuliah sudah sesuai

\section{Konversi Dengan Mata Kuliah Sudah Sesuai}

- Sangat Setuju $\quad$ Setuju $\quad$ Netral $\quad$-Tidak Setuju

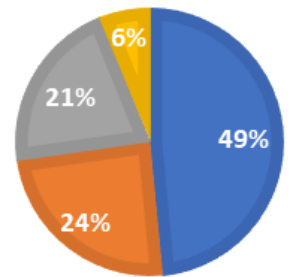

Gambar 1.3 konversi dengan mata kuliah sudah sesuai

Berdasarkan gambar 1.3 dapat dijeaskan bahwa mahasiswa merasa konversi dengan mata kuliah sudah sesuai sebanyak $83 \%$ (setuju dan sangat setuju), masih terdapat $21 \%$ merasa ragu-ragu bahkan $6 \%$ responden tidak setuju. Hal ini mengindikasikan bahwa masih ada mahasiswa yang mengkawatirkan akan konversi nilai mata kuliah.

d. Saya merasakan program magang MBKM mampu meningkatkan kompetensi diri

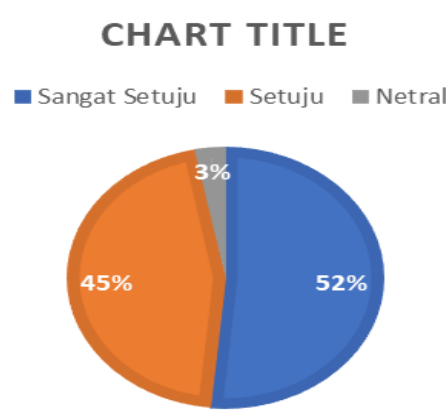

Gambar 1.4 Pie Chart mampu meningkatkan kompetensi diri

Berdasarkan gambar 1.4 dapat dijelaskan bahwa mahasiswa yang mengikuti program magang MBKM merasa kompetensi diri meningkat sebesar 97\%, sedangkan 3\% masih ragu-ragu akan kompetensi dirinya.

e. Saya merasakan program magang MBKM mampu meningkatkan kepercayaan diri 
Suryo Budi Santoso,Herni Justiana Astuti,Hadi Pamono,Nur Isna Inayati,Muhammad Hamka (Vol. 2, No. 1, February 2022)

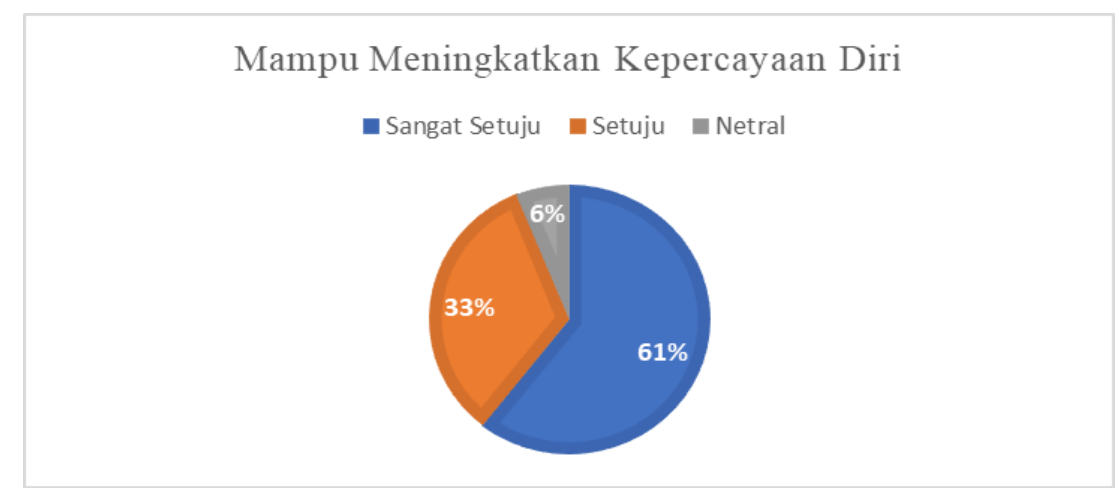

Gambar 1.5 Pie Chart mampu meningkatkan kepercayaan diri

Berdasarkan gambar 1.5 diperoleh informasi bahwa mahasiswa merasa dengan adanya program magang MBKM membuat mereka menjadi percaya diri sebesar $94 \%$, sedangkan 6\% masih ragu-ragu akan peningkatan kepercayaan diri mereka. Hal ini mengindikasikan bahwa program magang MBKM membuat mahasiswa percaya diri akan kemampuannya menyelesaikan pekerjaan yang diberikan kepadanya.

f. Saya merasakan program magang MBKM mampu meningkatkan kedisiplinan

Mampu Meningkatkan Kedisiplinan

@Sangat Setuju $\quad$ Setuju $\quad$ Netral

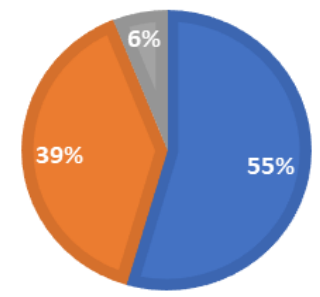

Gambar 1.6 Pie Chart mampu meningkatkan kedisiplinan

Berdasarkan gambar 1.6 dapat dilihat bahwa 94\% mahasiswa merasa dengan adanya program magang MBKM kedisplinan mereka meningkat, sedangkan 6\% masih ragu-ragu

g. Saya merasakan program magang MBKM mampu meningkatkan kemampuan komunikasi

Mampu Meningkatkan Kemampuan Komunikasi

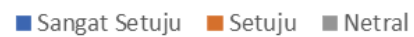

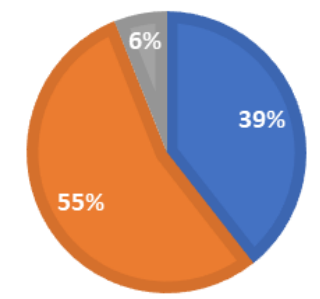

Gambar 1.7 Pie Chart mampu meningkatkan kemampuan komunikasi

Berdasarkan gambar 1.7 dapat dijelaskan bahwa mahasiswa merasa dengan adanya program magang MBKM mereka memiliki peningkatan kemampuan komunikasi sebesar $94 \%$ sedangkan $6 \%$ masih ragu-ragu.

h. Saya merasakan program magang MBKM mampu meningkatkan dalam menyelesaikan Vol.2 No.1 tugas yang diberikan 
CHART TITLE

- Sangat Setuju $\quad$ Setuju $\quad$ Netral

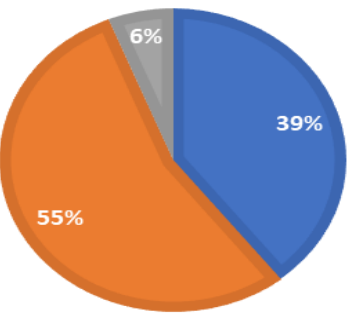

i. Saya merasakan program magang MBKM mampu meberikan kemampuan dalam pengambilan keputusan

\section{CHART TITLE}

- Sangat Setuju $\mathbf{n}$ Setuju $\mathbf{n}$ Netral

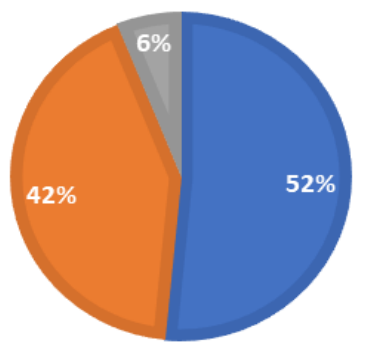

j. Saya merasakan program magang MBKM mampu mengimplementasikan etika kerja CHART TITLE

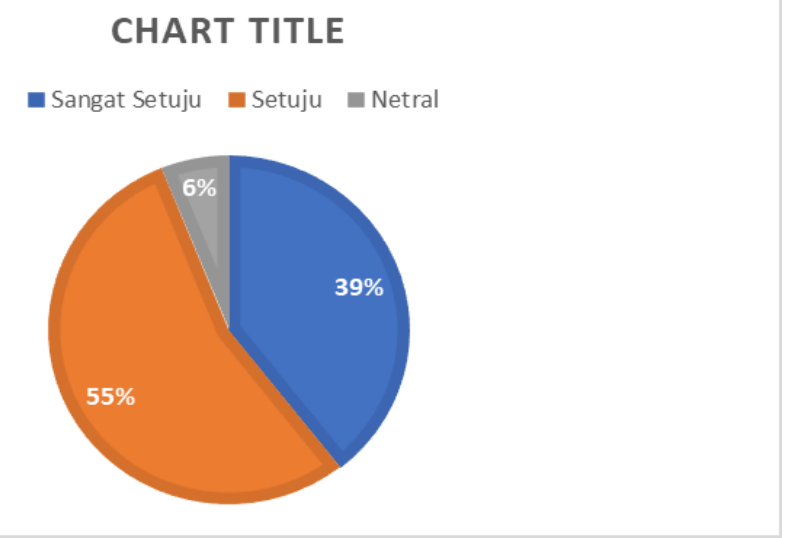

3. Jawaban terbuka responden Mahasiswa

Pengalaman apa saja yang bisa anda ungkapkan setelah mengikuti program MBKM?

\begin{tabular}{|c|l|c|}
\hline No & \multicolumn{1}{|c|}{ Jawaban } & \multicolumn{1}{|c|}{} \\
\hline 1 & $\begin{array}{l}\text { Lingkungan baru dan dapat menemui orang orang baru yang } \\
\text { sangat hebat }\end{array}$ & $3 \%$ \\
\hline 2 & Luarbiasa & $9 \%$ \\
\hline 3 & $\begin{array}{l}\text { Mengenal dunia pekerjaan secara langsung dan bertemu dengan } \\
\text { banyak }\end{array}$ & $6 \%$ \\
\hline 4 & $\begin{array}{l}\text { Saya jadi mengerti memulai bisnis dari nol,dan lebih bisa percaya } \\
\text { diri berbicara didepan orang }\end{array}$ & $6 \%$ \\
\hline 5 & bisa menambah relasi atau networking & $28 \%$ \\
\hline
\end{tabular}


Suryo Budi Santoso,Herni Justiana Astuti,Hadi Pamono,Nur Isna Inayati,Muhammad Hamka (Vol. 2, No. 1, February 2022)

\begin{tabular}{|c|l|c|}
\hline 6 & $\begin{array}{l}\text { Pengalaman baru bisa terjun langsung melihat proses produksi } \\
\text { UMKM }\end{array}$ & $3 \%$ \\
\hline 7 & $\begin{array}{l}\text { Dengan adanya program MBKM, saya bisa mengimplementasikan } \\
\text { mata kuliah secara langsung }\end{array}$ & $6 \%$ \\
\hline 8 & $\begin{array}{l}\text { Saya lebih memahami bagaimana cara bekerja di lembaga } \\
\text { keuangan syariah }\end{array}$ & $22 \%$ \\
\hline 9 & $\begin{array}{l}\text { Lebih percaya diri dan mendapatkan pengalaman yang belum } \\
\text { pernah saya dapatkan }\end{array}$ \\
\hline
\end{tabular}

\section{Hasil Analisis Data Mitra}

1. Statistik Deskriptif

Pelaksanaan magang sebagai implementasi Program MBKM dilaksanakan di 2 kelompok yaitu perbankan (Bank Syariah Indonesia dan Bank Jateng Syariah) sebanyak 16 mahasiswa dan magang pada UMKM sebanyak 16 mahasiswa. Pelaksanaan magang dalam program MBKM adalah baru meskipun program magang sebelumnya sudah dilaksanakan oleh FEB, sehingga perlu adanya evaluasi dari sisi mitra. Berikut statistic deskriptif jawaban mitra atas evaluasi mahasiswa magang seperti yang disajikan dalam tabel 3.1:

Tabel 3.1 Statistik deskriptif jawaban mitra

\begin{tabular}{|l|r|r|r|r|r|}
\hline & $\mathrm{N}$ & Minimum & Maximum & Mean & Std. Deviation \\
\hline X1 & 5 & 3.00 & 5.00 & 4.2000 & .83666 \\
X2 & 5 & 4.00 & 5.00 & 4.2000 & .44721 \\
X3 & 5 & 4.00 & 5.00 & 4.2000 & .44721 \\
X4 & 5 & 3.00 & 5.00 & 3.4000 & .89443 \\
X5 & 5 & 4.00 & 5.00 & 4.2000 & .44721 \\
X6 & 5 & 3.00 & 5.00 & 4.0000 & .70711 \\
X7 & 5 & 4.00 & 5.00 & 4.8000 & .44721 \\
X8 & 5 & 4.00 & 5.00 & 4.4000 & .54772 \\
X9 & 5 & 3.00 & 5.00 & 3.6000 & .89443 \\
X10 & 5 & 4.00 & 5.00 & 4.2000 & .44721 \\
Rata2 & 5 & 3.70 & 5.00 & 4.1200 & .50695 \\
Valid N & 5 & & & & \\
(listwise) & 5 & & & & \\
\hline
\end{tabular}

Berdasarkan tabel 3.1 bahwa nilai rata-rata pernyataan tertinggi pada kuesioner nomor X8 sebesar 4,80 dapat diartikan bahwa mahasiswa yang ikut program magang/MBKM memiliki rasa tanggung Jawab, sedangkan nilai rata-rata terendah pada pernyataan nomor X4 sebesar 3.40 dapat diartikan bahwa mahasiswa yang ikut program magang memiliki kemampuan Bahasa Inggris. Hal ini harus menjadi perhatian pengelola program MBKM untuk memasukkan persyaratan mahasiswa yang ikut magang memiliki kemampuan Bahasa Inggris. Secara keseluruhan pelaksaan MBKM dari tinjauan mitra menyatakan bahwa ratarata sebesar 4,12 atau setuju.

2. Jawaban Kuesioner Tertutup dengan responden mitra MBKM

a. Mahasiswa yang mengikuti Program Magang memberikan manfaat kepada perusahaan/instansi bapak ibu 


\section{Program Magang Memberikan Manfaat}

- Sangat Setuju $\mathbf{n}$ Setuju $\quad$ Netral

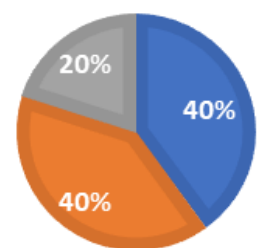

Gambar 3.1 Pie Chart Program Magang memberikan manfaat

Berdasarkan gambar 3.1 dijelaskan bahwa mahasiswa yang magang memberikan manfaat sebesar $80 \%$, sedangkan $20 \%$ mitra masih ragu-ragu akan manfaatnya. Hal ini mengindikasikan bahwa mahasiswa yang magang berkontribusi pada aktivitas tempat magang.

b. Mahasiswa yang mengikuti Program Magang memiliki integritas (etika dan moral)

\section{Memiliki Integritas (Etika Dan Moral)}

- Sangat Setuju Setuju

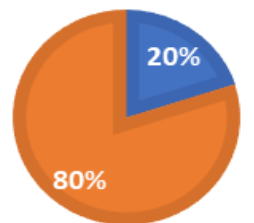

Gambar 3.2 Pie Chart Memiliki Integritas (Etika Dan Moral)

Berdasarkan gambar 3.2 dapat terlihat bahwa menurut mitra, mahasiswa yang magang memiliki intergitas yaitu mengenai etika dan moral mereka sebesar $100 \%$ (sangat setuju dan setuju).

c. Mahasiswa yang mengikuti Program Magang memiliki keahlian dan ketrampilan

Memiliki Keahlian dan Ketrampilan)

- Sangat Setuju $\quad$ Setuju

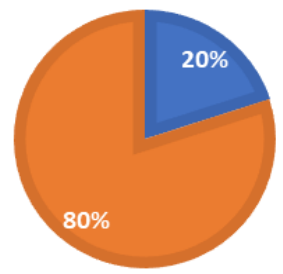

Gambar 3.3 Pie Chart Memiliki Keahlian dan Ketrampilan

Berdasarkan tabel 3.3 dapat dijelaskan bahwa mahasiswa yang ikut program magang atas evaluasi dari mitra memiliki keahlian dan ketrampilan sebesar $100 \%$ (sangat setuju dan setuju).

d. Mahasiswa yang mengikuti Program Magang memiliki kemampuan Bahasa Inggris 
Suryo Budi Santoso,Herni Justiana Astuti,Hadi Pamono,Nur Isna Inayati,Muhammad Hamka (Vol. 2, No. 1, February 2022)

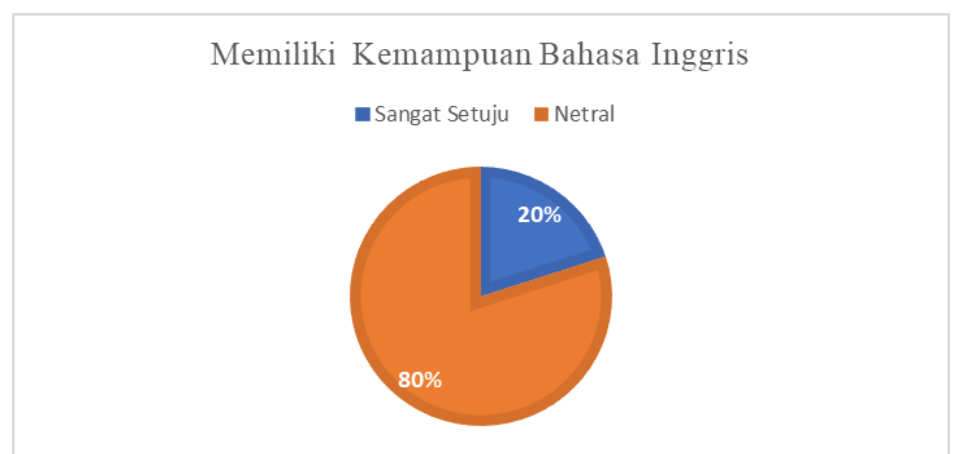

Gambar 3.4 Pie Chart memiliki kemampuan Bahasa Inggris

Berdasarkan gambar 3.4 menjelaskan bahwa hanya 20\% dinilai memiliki kemampuan Bahasa Inggris sebesar 20\%, namun ada $80 \%$ mitra yang ragu-ragu atas kemampuan Bahasa Inggris mahasiswa magang.

e. Mahasiswa yang mengikuti Program Magang memiliki kemampuan mengoperasikan Teknologi Informasi

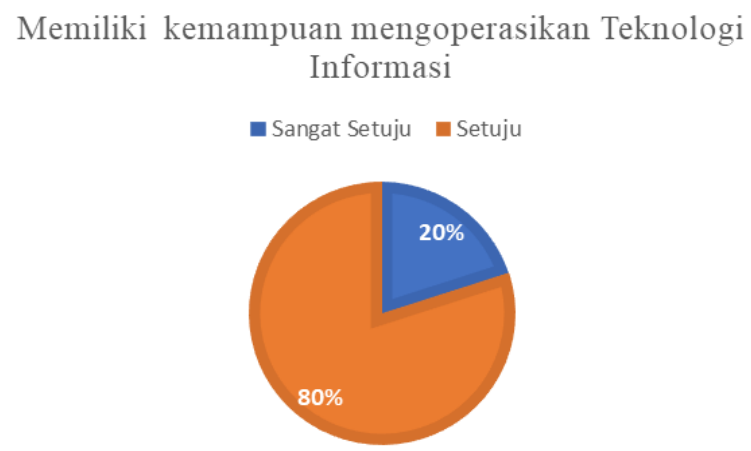

Gambar 3.5 Pie Chart Memiliki kemampuan mengoperasikan Teknologi Informasi Berdasarkan gambar 3.5 dapat dijelaskan bahwa berdasarkan penilaian mitra mahasiswa magang sebesar 100\% memiliki kemampuan mengoperasikan Teknologi Informasi (sangat setuju dan setuju).

f. Mahasiswa yang mengikuti Program Magang memiliki kemampuan Komunikasi verbal

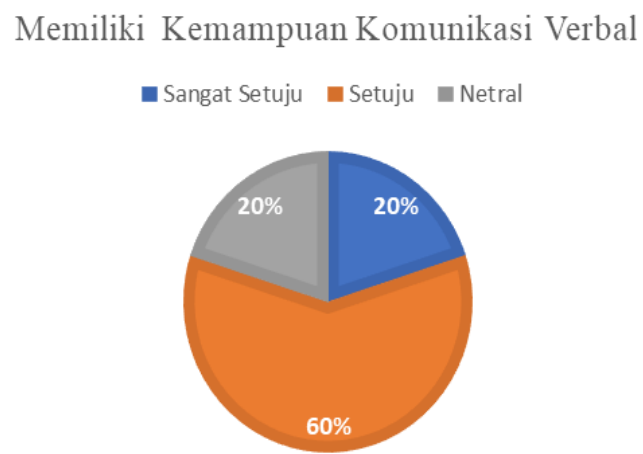

Gambar 3.6 Pie Chart Memiliki Kemampuan Komunikasi Verbal

Berdasarkan gambar 3.6 dapat dijelaskan bahwa menurut penilaian mitra, mahasiswa magang Memiliki Kemampuan Komunikasi Verbal sebanyak 80\%, sedangkan yang masih ragu-ragu menilai sebesar $20 \%$.

g. Mahasiswa yang mengikuti Program Magang memiliki rasa Tanggung Jawab 
Memiliki memiliki rasa Tanggung Jawab

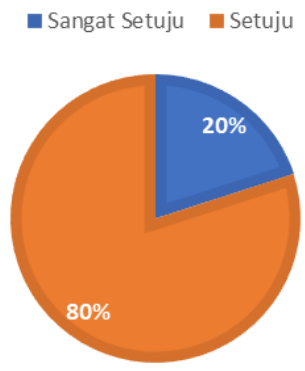

Gambar 3.7 Pie Chart Memiliki memiliki rasa Tanggung Jawab

Berdasarkan gambar 3.7 menjelaskan bahwa penilaian mitra sebesar 100\% mahasiswa magang i memiliki rasa tanggung Jawab (sangat setuju dan setuju). Hal ini mengidikasikan bahwa mahasiswa magang selalu mengerjakan tugas yang diberikan dengan rasa tanggung jawab.

h. Mahasiswa yang mengikuti Program Magang memiliki kemampuan Kerjasama Tim

Memiliki Kemampuan Kerjasama Tim

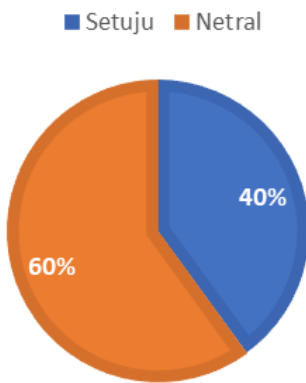

Gambar 3.8 Pie Chart Memiliki Kemampuan Kerjasama Tim

Berdasarkan gambar 3.8 menjelaskan bahwa atas penilaian mitra, mahasiswa memiliki Kemampuan Kerjasama Tim sebesar 60\% sedangkan $40 \%$ mitra ragu-ragu dalam menilai kemampuan mahasiswa memiliki Kemampuan Kerjasama Tim. Hal ini mengindikasikan bahwa mahasiswa magang perlu diberi pembekalan kemampuan untuk bekerjasama dalam tim.

i. Mahasiswa yang mengikuti Program Magang memiliki kemampuan dalam pemecahan masalah

Memiliki Kemampuan Dalam Pemecahan Masalah

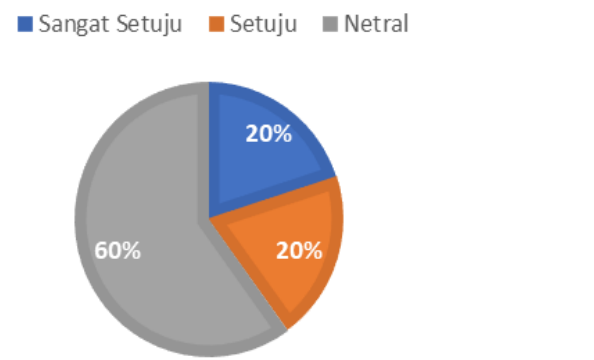

Gambar 3.9 Pie Chart memiliki kemampuan dalam pemecahan masalah

Berdasarkan gambar 3.9 dapat dijelaskan bahwa mitra menilai mahasiswa magang memiliki kemampuan dalam pemecahan masalah sebesar $40 \%$, sedangkan $60 \%$ mereka belum sepenuhnya memiliki kemampuan untuk memecahkan masalah. Hal ini 
mengindikasikan bahwa pengelola program perlu memberikan pembekalan dalam bentuk simulasi memecahkan masalah.

j. Bapak Ibu merasa puas dengan kinerja mahasiswa yang mengikuti Program magang

Merasa puas dengan kinerja mahasiswa

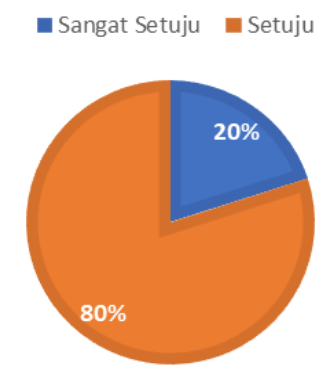

Gambar 3.10 Pie Chart merasa puas dengan kinerja mahasiswa

Berdasarkan gambar 3.10 dapat dijelaskan bahwa mitra merasa puas dengan kinerja mahasiswa sebesar 100\% (sangat setuju dan setuju). Hal ini mengindikasikan bahwa mahasiswa mengerjakan tugas yang diberikan sesuai dengan harapan mitra.

3. Jawaban pertanyaan terbuka Mitra

Tabel 3.2 pertanyaan terbuka dengan responden mitra

\begin{tabular}{|c|l|c|}
\hline No & \multicolumn{1}{|c|}{ Pertanyaan } & Jawaban \\
\hline 1 & $\begin{array}{l}\text { Apakah bapak ibu menginginkan } \\
\text { pelaksanaan magang mahasiswa FEB UMP } \\
\text { diperpanjang? }\end{array}$ & Ya \\
\hline 2 & $\begin{array}{l}\text { Berapalamakah idealnya magang mahasiswa } \\
\text { FEB UMP dilaksanakan di perusahaan/ } \\
\text { instansi bapak ibu? }\end{array}$ & 3-6 bulan \\
\hline 3 & $\begin{array}{l}\text { Pada periode apakah magang mahasiswa } \\
\text { kami sebaiknya dilaksanakan diperusahaan/ } \\
\text { instansi bapak ibu? }\end{array}$ & $\begin{array}{c}\text { Januari-Februari, } \\
\text { Juli-Agustus }\end{array}$ \\
\hline 4 & $\begin{array}{l}\text { Berapa jumlah mahasiswa magang yang } \\
\text { sebaiknya di tempatkan di perusahaan/ } \\
\text { instansi bapak ibu? }\end{array}$ & Sesuai kebutuhan \\
\hline 5 & $\begin{array}{l}\text { Untuk masa yang akan datang, apakah } \\
\text { dimungkinkan kerjasama kemitraan secara } \\
\text { formal dengan perusahaan/ instansi bapak ibu } \\
\text { terkaitan dengan pelaksanaan magang } \\
\text { mahasiswa kami? }\end{array}$ & Ya \\
\hline
\end{tabular}

Berdasarkan tabel 3.2 dapat dijelaskan bahwa mitra menginginkan pelaksanaan magang diperpanjang minimal 3 bulan karena untuk beradaptasi membutuhkan waktu 1 bulan setelah itu baru memahami pekerjaan. Jangka waktu 3-6 bulan bisa menilai kinerja mereka, hal ini bermanfaat untuk early recruitment karyawan baru, dengan pertimbangan mitra sudah bisa menilai kinerja mereka dan tidak mengajari dari awal. Periode magang sebenarnya bisa kapan saja, kalua selama ini mahasiswa magang untuk mengisi waktu luang saat liburan sehingga menumpuk di bulan-bulan liburan. Jumlah mahasiswa magang sesuai kebutuhan (untuk perbankan dibatasi oleh peraturan kantor pusat), bahkan untuk magang UMKM jika program magang MBKM pertama berhasil akan membutuhkan banyak mahasiswa magang untuk mendampingi UMKM memperbaiki kinerja usahanya. 


\section{KESIMPULAN DAN SARAN}

\section{Kesimpulan}

Program MBKM merupakan program baru, sehingga masih dalam tahap penyesuaian untuk mencapai optimalisasi progrm. Namun demikian dampak pelaksanaan program MBKM sudah dirasakan mahasiswa dan dosen. Mahasiswa dapat belajar aplikasi keilmuan dan softskill dari program magang. Dosen pendamping juga dapat menerima masukan yang aplikatif dari dari mitra, untuk dapat diterapkan pada proses pembelajaran.

\section{Saran}

Saran yang dapat dirkomendasikan antara lain:

a. Sosialisasi program MBKM dengan lebih intens lagi

b. Ada pendanaan dari kementerian terkait MBKM

c. Perlu ada kebijakan agar mitra (instansi dan unit usaha) untuk lebih kooperatif dalam mendukung program MBKM

\section{DAFTAR PUSTAKA}

Angriani, A.D. dan Kusumayanti, A.N.Y. (2020). Pengembangan media pembelajaran digital book pada materi aljabar. Delta-Pi: Jurnal Matematika Dan Pendidikan Matematika, 9(2): 1330

Arifin, S., \& Muslim, M. O. H. (2020). Tantangan Implementasi Kebijakan "Merdeka Belajar, Kampus Merdeka" pada Perguruan Tinggi Islam Swasta di Indonesia. Jurnal Pendidikan Islam Al-Ilmi, 3(1)

Ames, A., Smith, K. L., Sanchez, E. R. H., Pyle, L., Ball, T., \& Hawk, W. J. (2017). Impact and persistence of ethical reasoning education on student learning: results from a modulebased ethical reasoning educational program. International Journal Ethics and Education, 2(1): 77-96

Arsanti, M. (2018). Pengembangan bahan ajar mata kuliah penulisan kreatif bermuatan nilai-nilai pendidikan karakter religius bagi mahasiswa Prodi PBSI, FKIP, Unissula. Jurnal Kredo, 1(2): 71-90

Barnard-Brak, L., Paton, V. O., \& Lan, W. Y. 2010. Profiles in self-regulated learning in the online learning environment. The International Review of Research in Open and Distributed Learning, 11(1), 61-80. https://doi.org/10.19173/irrodl.v11i1.769

Bele, F., \& Made, D. (2018). Inovasi pembelajaran elektronik dan tantangan guru abad 21. Jurnal Penelitian dan Pengkajian Ilmu, 2(1): 10-18

Bustomi, A. (2020). Implikasi covid-19 terhadap pembelajaran di perguruan tinggi. Jurnal Tawadhu, 4(1): 1007-1017

Davis, F. D. 1989. Perceived usefulness, perceived ease of use, and user acceptance of information technology. MIS Quarterly. 13(3): 319-39

DeLone, W.H. dan McLean, Ephraim R. 2003. The DeLone and McLean model of information systems success: a ten year update. Journal of Management Information Systems. 19(4): 9-30

Dewantara, I. P. M. 2020. Curriculum changes in Indonesia: Teacher constraints and students of prospective teachers' readiness in the implementation of thematic learning at low grade primary school. Elementary Education Online, 19(2), 1047-1060. https://doi.org/10.17051/ ilkonline.2020.696686

Dewi, W.A.F. 2020. Dampak covid-19 terhadap implementasi pembelajaran daring di sekolah dasar. Jurnal Pendidikan. 2(1): 55-61

RAAR Fathan Robby. 2020. Hardiknas 2020 Merdeka Belajar Di Tengah Covid-19. Vol.2 No.1 (http://jurnalposmedia.com/hardiknas-2020-merdeka-belajar-ditengah-covid-19

Fadli, F., Astuti, S. I. D., \& Rukiyati, R. (2020). Techno-resilience for teachers: Concepts and action. TEM Journal, 9(2): 820-825 
He, W., Xu, G., and Kruck, S. E. (2019). Online IS education for the 21st century. J. Inform. Syst. Educ. 25, 101-105. Daniel, S. J. (2020). Education and the COVID-19 pandemic. Prospects 49: 91-96

Herliandry, L. D., \& Suban, M. E. (2020).Pembelajaran pada masa pandemi covid-19. Jurnal Teknologi Pendidikan, 22(1): 65-70

Lipscombe, K., Buckley-Walker, K., \& McNamara, P. (2020). Understanding collaborative teacher teams as open systems for professional development. Professional Development and Education, 46(3): 373-390

Prayogo. 2020. Peluang Reformasi Pendidikan di Tengah Pandemi Covid-19. https://www.y. prayogo.kalderanews.com/2020/05/peluang-reformasi-pendidikan-di-tengah-pandemicovid-19-begini-kata-mendikbud/

Sousa, M.J.; Cruz, R.; Martins, J.M. Digital Learning Methodologies and Tools-A Literature Review. In Proceedings of the Edulearn17 Proceedings, Barcelona, Spain, 3-5 July 2017; pp. 5185-5192.

Sousa, M.J.; Rocha, Á. Corporate Digital Learning-Proposal of Learning Analytics Model. In Trends and Advances in Information Systems and Technologies; WorldCIST'18 2018, Advances in Intelligent Systems and Computing; Rocha, Á., Adeli, H., Reis, L.P., Costanzo, S., Eds.; Springer: Cham, Switzerland, 2018; Volume 745

Tri, P., \& Karya, M. (2020). Analisa Minat Membaca Antara E-Book Dengan Buku Cetak Mengunakan Metode Observasi Pada Politeknik Tri Mitra Karya Mandiri. Jurnal IKRAITH Ekonomika, 4(2):158-163

Widiyono, A., Irfana, S., \& Firdausia, K. (2021). Implementasi Merdeka Belajar Melalui Kampus Mengajar Perintis Di Sekolah Dasar. Metodik Didaktik: Jurnal Pendidikan Ke-SD-An, $16(2)$

Winatha, K. R. (2018). Pengembangan E-modul Interaktif Berbasis Proyek Mata Pelajaran Simulasi Digital. Jurnal Pendidikan Teknologi Dan Kejuruan, 15(2). https://doi.org/10.23887/jptk-undiksha.v15i2.14021 